\title{
M-learning for the Art of Drawing: Informal Learning for a Digital Age
}

\author{
https://doi.org/10.3991/ijim.v12i5.9207 \\ Chananchida Yuktirat, Apisak Sindhuphak, and Krissana Kiddee \\ King Mongkut's Institute of Technology Ladkrabang, Bangkok, Thailand \\ $57603035 @ \mathrm{kmitl} . \mathrm{ac} . \mathrm{th}$
}

\begin{abstract}
Mobile learning (M-learning) has become part of a rich mix of new features and facilities in the teaching and learning process, and with the advent and proliferation of the smartphone, M-learning is reaching new heights. In the art world, M-learning is also being explored, and as students can be connected to their teacher from anywhere in the world, there is no longer the need for a physical studio to learn the magic of art. The researchers therefore set out to create a course using digital technologies for teaching the Art of Drawing online. Initially, the researchers made use of the Delphi method to query a panel of 19 experts in the fields of art education, educational technologists and artists to gather their input for an online, M-Learning course model. After which, 248 Facebook members belonging to the 'Society of the Professional Art Teachers Development of Thailand' were selected by use stratified random sampling. From these members, 201 opted to participate in a 2-month M-learning course concerned with the Art of Drawing. Results revealed that both the experts and the course students found the use of digital tools such as the iPad, tablet, and smartphone as very appropriate in learning the Art of Drawing. The same was true for the applications as well.
\end{abstract}

Keywords—informal learning, learning communities, mobile learning, smartphones

\section{Introduction}

Matin and Parker stated that virtual classrooms allow students and teachers to communicate synchronously using features such as audio, video, text chat, interactive whiteboard, and application sharing [1]. Additionally, mobile learning (M-learning) has become part of a rich mix of new features and facilities in the teaching and learning process [2]. With the advent and proliferation of the smartphone, M-learning is reaching new heights with its potential in the learning process, which is just now being explored and understood [3]. However, after a review of $102 \mathrm{M}$-learning projects and 1,469 publications, Frohberg, Göth and Schwabe, stated that there is no consensus about the definition of the term itself [4]. There are however, countless conferences and journals marketing to its use, with the first M-learning conference taking place in 2002 . 
Fig. 1 shows the task model developed for M-learning by Taylor, Sharples, O'Malley, Vavoula, and Waycott [5], which had its beginnings in activity theory [6], and was explicitly designed to structure and analyze M-learning - both on a detailed level and a project meta-level. Both Sharples and Taylor expanded Engeströms model, which fails to resolve the complex interdependencies and dialectic of learning and technology [4].

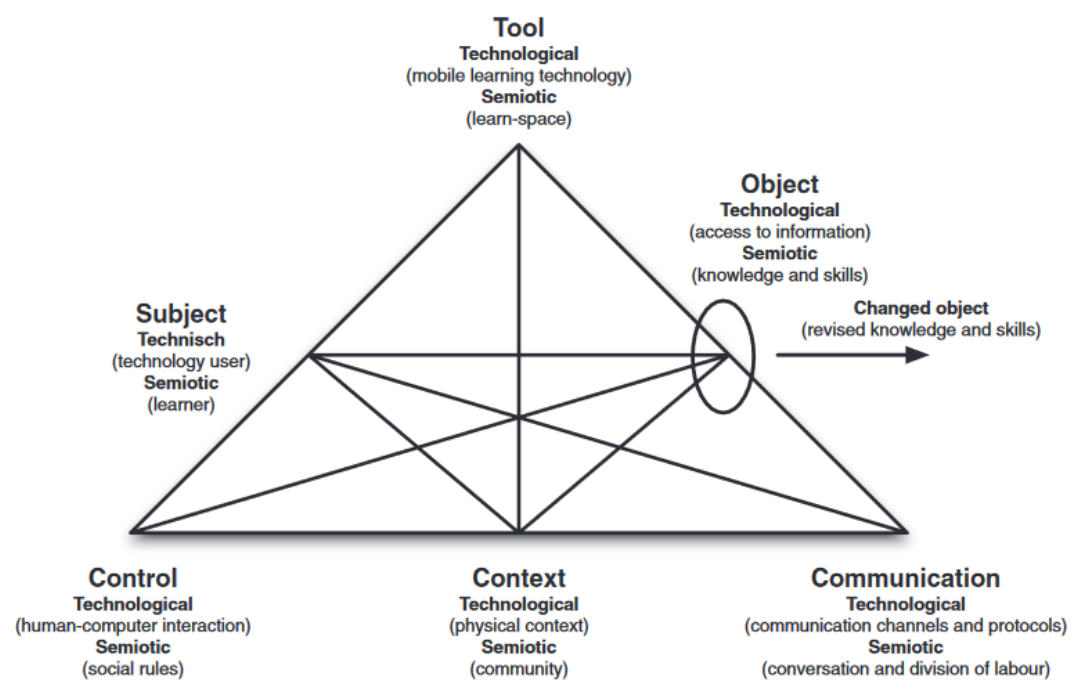

Fig. 1. M-learning task model

(Source: [5], [7])

Finkelstein also listed five functions that are served by real-time synchronous interaction in a learning environment [8]. These included instruction, collaboration, socialization and informal exchange, support, and extended outreach. This is supported by Cao, Griffin, and Bai which also suggested that M-learning interaction effectively raises student satisfaction [9], and that "synchronous tools are more effective for the social' side of education" [10 p. 131].

In the art world, M-learning is also being explored, and as students can be connected to their teacher from anywhere in the world, there is no longer the need for a physical studio to learn the magic of art. In fact, M-learning is characterized by the students' mobility, the chance of having localized information, the large amount of data that can be collected during a learning session, the advantages of the technologies and the social dynamics that characterize the context in which learning takes place [11].

The Internet has opened up the possibly of exploring the world's museum treasures online, and learning through the interaction of instructional material, seminars, online classes, etc. But can the creation of art be taught with the use of digital technologies such as smartphones and M-learning? Some think it can.

Austria has been a leading innovator in initiatives to develop ePortfolios, which are now a central element in national learning policies [12]. In this environment, team- 
work is crucial and 'copying' is encouraged. Furthermore, teamwork and community learning has become a higher motivation for learning then learning as a single person [13]. With such community learning styles, the possibilities at judging somebody is expanded. When combined with a LMS (learning management system), the ePortfolio becomes a good backbone to support different kinds of peer evaluation and coaching processes [12] [14]. Additionally, mobile phones are being used as online portfolios, which is a great way to share knowledge and techniques with other students and professionals.

M-learning, therefore, is one model that encourages and challenges a learner. Internet searches show that there are 1,000 s of art classes being taught online, with many offered by universities, for-profit colleges, and online course sites like CreativeLive and Skillshare. Many make use of pre-recorded material, with aspiring artists paying for courses packaged with personal instructor feedback. Social media platforms such as Instagram and Facebook drive traffic to the sites, which allow short glimpses of course material.

\subsection{Informal Art of Drawing and Creative Self-Expression}

Amabile wrote that fostering a creative environment helps children engage in abstract and analytical thinking, sharpens their visual-spatial acuity, and allows them to be more receptive to out-of-the-box thinking [15]. Also, color can help children develop vocabulary, complex thinking, and keen observation [16]. Studying art and painting can therefore be a starting point in developing creative human skills and knowledge, as painting is a path to the dimension of imagination. Even more important however, is that the art of painting is a search for identity, which creates happiness and protects the identity of the drawer.

In the early 1980's Discipline-Based Art Education (DBAE) emerged as a curriculum, incorporating art history, art criticism, aesthetics and art production, " ... to produce educated adults who are knowledgeable about art and its production and responsive to the aesthetic properties of works of art and other objects [17]. Eisner discussed the idea of DBAE, which is designed to encourage instruction that supports and expands creative self-expression [18]. DBAE helps a student learn not only how to create art, but how to respond to, interpret, and judge art. These four disciplines include aesthetics, art criticism, art history and art production [19-20]. This is consistent with Barkan which stated that the art educator cannot avoid theory, because he must be guided by it; hence, "he must synthesize the knowledge in art of the artist, and the knowledge about art of the aesthetician, the critic, and the historian" [21, p.243].

Early testing of the DBAE curriculum combined with technology was conducted by Wolf [22]. Using audio-visual programs, art teachers taught US fifth-graders use of line, color and composition when creating still life drawings. As part of Wolf's related research, he introduced The National Art Education Association's (NAEA) 1965-66 study which examined the use of audio-visual programs in art education [23]. This early study made recommendations for creating effective programs "...that would 
be aesthetically designed, incorporate contemporary art education theory, and be specifically planned for use with a specific school population" [23, p.6].

Later studies, such as the 1971 Brouch Study, attempted to fine-tune the use of audio-visual materials, namely slides, in art education. This study was conducted to investigate the benefits of slide-tape presentations as a supplement in art education, and to determine whether the use of these presentations effected the outcome of student work. In addition, Wolf introduced the Othman study, which evaluated the use of computer interactive video and its effect on the instruction of college undergraduate students [22].

Moving into the $21^{\text {st }}$ Century classroom, technology has once again opened up new frontiers into teaching. Bidarra, Figueiredo, and Natálio examined the potential of mobile platforms, such as iOS and android, for Portuguese $4^{\text {th }}$ grade students' environmental studies classes [24]. Preliminary results revealed very good usability and promising pedagogical potential in the proposed models. This was consistent with Usal and Şirin which reported that M-learning devices and technologies, have had broad repercussions in the teaching-learning process in art education in Turkey, as it opens significant opportunities for art education and the potential to provide alternative perspectives [25]. M-learning therefore, makes it possible to work with different kinds of virtual materials, and to display learning products at any time and place.

\section{$1.2 \quad$ Informal Art through M-learning}

Although the development of an informal process of learning art through Mlearning is not new, taking advantage of new digital age tools such as iPads, tablet, phablets and smartphones for the teaching of art is a technologically advanced media for art education. As M-learning is a multi-media learning system, creation of a virtual environment in which learning resources are easily downloaded and classrooms are on digital devices, increases the freedom to learn. It is also a stimulus for research and collaboration, allowing interactions across cultures, as well as the immediate interaction between the teacher and the learner.

Furthermore, with the ever increasing complexity, cost, and investment in education, E-learning and M-learning have demonstrated great potential to society as they reduce cost and allow training at any time or place [26]. Furthermore, the content if learner-centered, which also allows the more efficient allocation of available educational resources, such as teachers and time. One of the mobile technologies strongest argument is their availability, where mobile devices can be accessed much easier than desktops [27]. It also expands educational channels and reduces disparities in social, economic, time, distance, including age, gender and health of learners. The opportunity to learn from the experience is continuous and limitless, with the use of apps developed specifically for following university subjects highly valued by students as a new format which both supports and enhances learning practices while also providing not only further opportunities to establish connections and relations with their subjects, but also fostering collaborative work among students and professors [28]. And finally, digital art and painting has several advantages over the manual painting, as it allows easier manipulation, color combinations, and other aesthetic applications [29]. 
This technological and M-learning learning approach allows an easy approach in implementing an artist's imagination and virtual thought (Table 1). This paper therefore explores the learning of art and drawing by use of M-learning and blended learning [30].

Table 1. Applications for Digital Sketching/Digital Painting, Skills, and Devices

\begin{tabular}{|l|l|l|}
\hline \multicolumn{1}{|c|}{ Applications } & \multicolumn{1}{c|}{ Skills } & \multicolumn{1}{c|}{ Appropriate Platforms } \\
\hline SketchBook & Draw + Painting & iPad, Tablet, SmartPhone \\
\hline Pen \& Ink & Draw + Painting & iPad, SmartPhone \\
\hline Concepts & Draw + Painting & iPad, Tablet \\
\hline Sketches & Draw + Painting & iPad, SmartPhone \\
\hline MediBang Paint & Draw + Painting & iPad, Tablet, SmartPhone \\
\hline ibisPaint X & Draw + Painting & iPad, Tablet, SmartPhone \\
\hline Procreate & Draw + Painting & iPad, SmartPhone \\
\hline Art Set & Draw + Painting & iPad, Tablet, SmartPhone \\
\hline UBrush Pro & Draw + Painting & iPad, SmartPhone \\
\hline Sketch Pad & Draw + Painting & iPad, SmartPhone \\
\hline LINE Brush & Draw + Painting & iPad, Tablet, SmartPhone \\
\hline MyBrushes Pro & Draw + Painting & iPad, Tablet, SmartPhone \\
\hline ArtRage & Draw + Painting & iPad, Tablet, SmartPhone \\
\hline Adobe Draw & Draw + Painting & iPad, Tablet, SmartPhone \\
\hline
\end{tabular}

\subsection{Research Objectives}

1. To develop a model for the teaching and learning of art through an informal Mlearning process.

2. It was also intended to better understand the terms and limitations of digital technology, such as 4/5G, PDAs (personal data assistants such as tablets and iPads), Smartphones, WiFi, Bluetooth, and wireless.

3. To evaluate multimedia and online learning channels through the use of triangulation of data analysis.

\section{Research Scope}

\subsection{Phase 1}

Phase 1 consisted of a step-by-step process to study M-learning components that are consistent and supported in a digital age, while learning the art of drawing. Further research was undertaken in the development of 'eportfolios' [12], and which methods and technologies are best for their collaborative use. Also, this phase was concerned with the collection of student behavior, and their observation techniques, in learning and practicing art in a classroom and by the use of digital technologies. Finally, this phase made use of semi-structured interviews with artists and art profes- 
sionals to learn their thoughts concerning the use of digital devices in developing and teaching creative art. Building upon these interviews, and a collection of related theories, Fig. 2 was developed and is presented as the study's informal learning analytics model. The learning analytic model can help define the what, why, how, and who within the M-learning process.

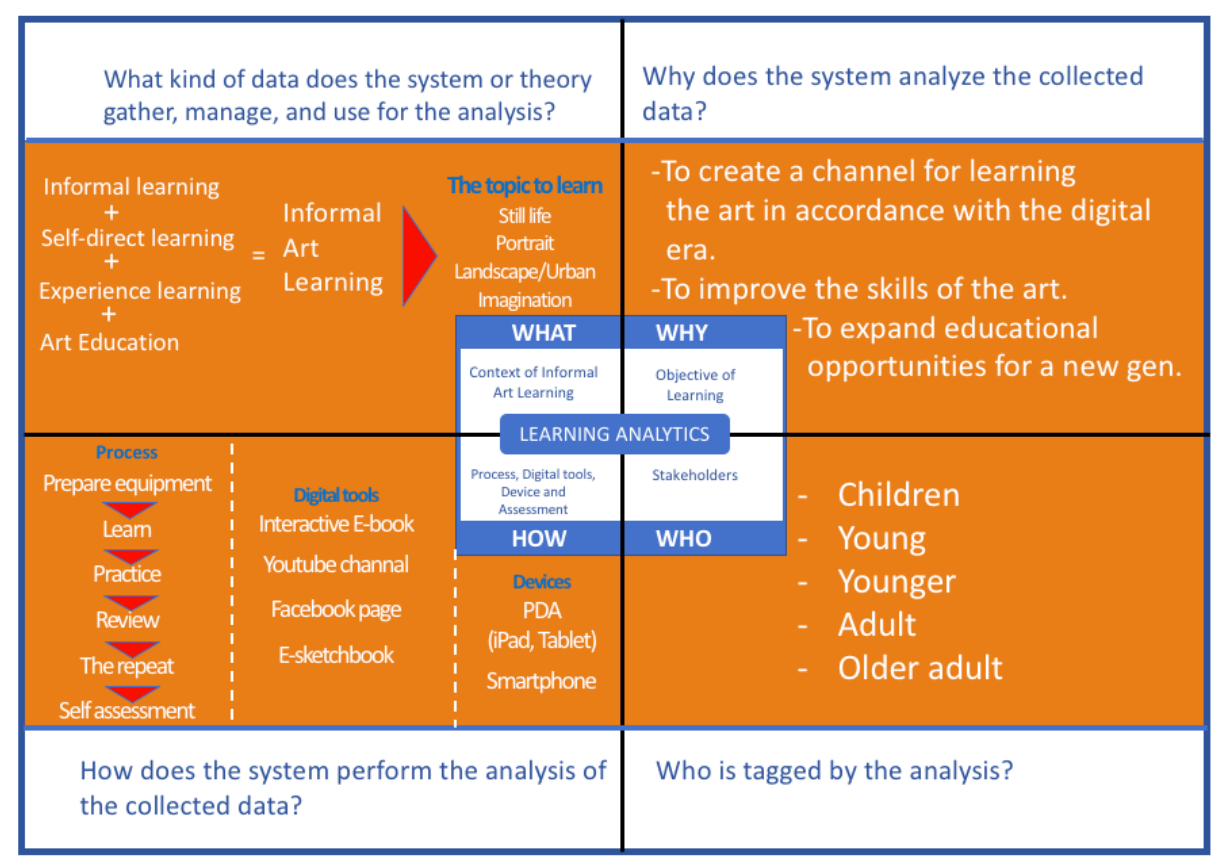

Fig. 2. M-learning analytics model

(Source: The Author)

\subsection{Phase 2}

Phase 2 consisted of the development of a step by step model in which art was taught through informal (M-learning) processes and multimedia forms through various channels (Fig. 3). The researchers made use of the Delphi method to query a panel of 19 experts in the fields of art education, educational technologists and artists [31]. A structured interview format was used three times to determine the consistency of the information, and to determine a corresponding development direction. Analysis then made use of descriptive statistics, including frequency value, percentage, average, standard deviation, and One Sample $t$ Test to confirm results and apply to the next phase. 


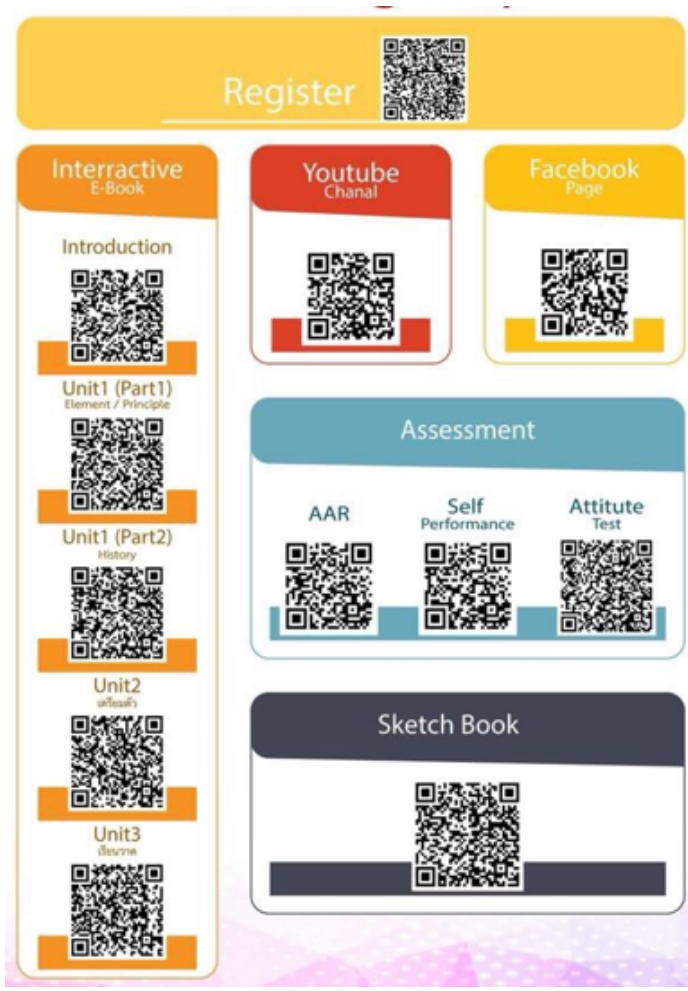

Fig. 3. M-learning quick response (QR) map Source: The Authors - https://www.facebook.com/IALmodel/

\subsection{Phase 3}

Phase 3 was concerned with developing an informal format to learn the art of drawing and painting [32]. From this, an effort was made to explain in detail the context and phenomena that comes from learning. In this phase, Facebook social media was used in helping instruct, communicating and evaluating the development of individuals enrolled in an M-learning art-based learning program. From this, the students' attitudes were evaluated and analyzed by use of descriptive statistics, including mean $(\bar{x})$ and standard deviation (SD). The data was stored and used to interpret the theory. The synthesis was divided into three dimensions as follows:

Dimension 1 - The role of the learning style in the art of drawing through Mlearning and continuous learning.

Dimension 2 - Performance and appropriateness of digital tools such as PDAs and Smartphones in the teaching and learning of the art of drawing through basic applications.

Dimension 3 - Multimedia and online learning channels. In this paper, triangulation of data analysis techniques provided validation [33], which ensured the reliability of the acquired information. 
Furthermore, the sequence for learning to draw included four groups, including still life drawing, landscape/urban sketching, portraiture/figures composition and fantasy and imagination for two months. In drawing, each group was divided into three levels which included sketching/writing structure, light and shadow and coloring (Fig. 4).

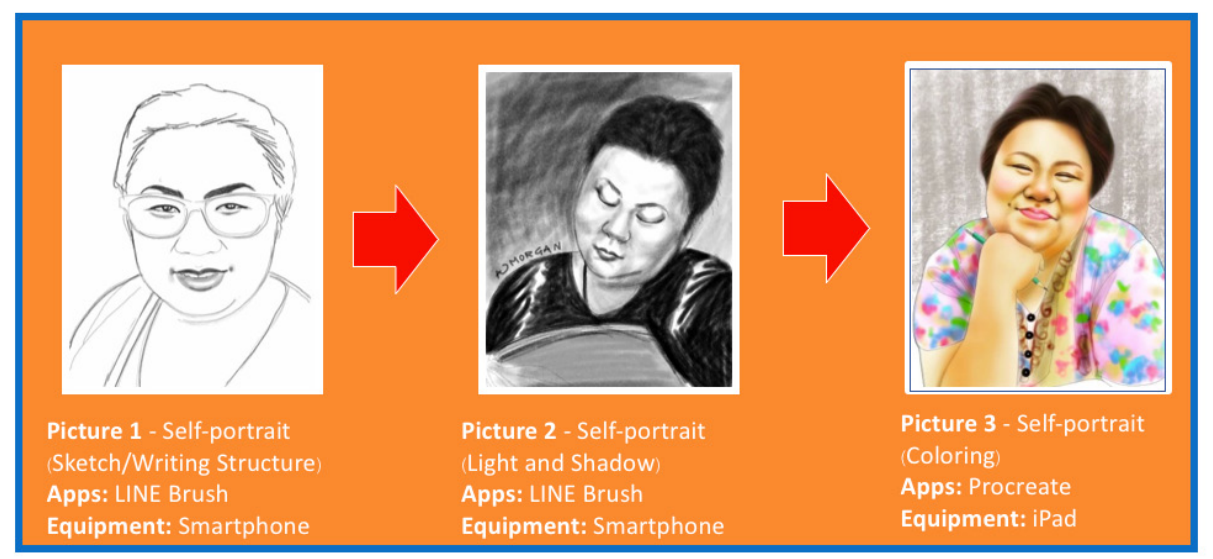

Fig. 4. M-learning 3-level sketching/writing structure, light and shadow and coloring process

\section{$3 \quad$ Methods}

\subsection{Population and Sample}

Initially, from a population of 423 members belonging to the 'Society of the Professional Art Teachers Development of Thailand', stratified random sampling was used to contact 248 individuals who had access to interactive Facebook pages (https://www.facebook.com/IALmodel/). From this process, 201 individuals registered and downloaded course material starting on 28 November 2016, continuing through 25 April 2018.

After enrollment, a two-month time table was established for the completion of the course. During this period, there were semi-structured or guided interviews, in-depth interviews, and open unlimited question/answer sessions via video call and talk through Facebook's inbox. The scale used to measure the art student M-learning course satisfaction consisted of a 5-level, Likert type agreement scale [34]. The scales used were as follows: 4.50-5.00 indicated very appropriate, 3.50-4.49 indicated good for use, 2.50-3.49 indicated appropriate for medium level applications, 1.50-2.49 indicated suitable for use, 1.00-1.49 indicated no quality in use and needed improvement. 


\section{$4 \quad$ Results}

\subsection{Participants' characteristics}

Initially, from a population of 423 members belonging to the 'Society of the Professional Art Teachers Development of Thailand', stratified random sampling was used to contact 248 individuals who had access to interactive Facebook pages (https://www.facebook.com/IALmodel/). From this process, 201 individuals registered and downloaded course material starting on 28 November 2016, continuing through 25 April 2018 (Table 2).

M-learning course participants consisted of $56.2 \%$ female $43.8 \%$ male. Most (72.6\%) were 40 years old or younger and had university degrees (89.6\%). Although targeted at teachers, it was interesting to note that $39.3 \%$ indicated they were a 'temporary employee' (contract teacher). As is well known, teacher salaries are low, and the survey confirmed this as $28.4 \%$ indicated a salary of less than 15,000 baht per month (\$US455). Also, 34.3\% were taking the course over a mobile network and did so 'to learn something new' $(38.3 \%)$ or 'for self-development' (28.4\%).

Table 2. Participants' Characteristics $(n=201)$

\begin{tabular}{|c|c|c|c|}
\hline Characteristics & Description & Participant No. & Percent \\
\hline \multirow{3}{*}{ Sex } & Male & 88 & 43.8 \\
\hline & Female & 113 & 56.2 \\
\hline & Total & 201 & 100 \\
\hline \multirow{4}{*}{ Age } & $18-40$ years of age & 146 & 72.6 \\
\hline & 41-65 years of age & 35 & 17.4 \\
\hline & Over 65 years of age & 20 & 10 \\
\hline & Total & 201 & 100 \\
\hline \multirow{3}{*}{ Education } & University level. & 180 & 89.6 \\
\hline & Technical or vocational level & 21 & 10.4 \\
\hline & Total & 201 & 100 \\
\hline \multirow{6}{*}{ Profession } & Government official. & 26 & 12.9 \\
\hline & Employee/and government employee & 58 & 28.9 \\
\hline & Temporary employee & 79 & 39.3 \\
\hline & Entrepreneur & 15 & 7.5 \\
\hline & Unemployed & 23 & 11.4 \\
\hline & Total & 201 & 100 \\
\hline \multirow{4}{*}{ Employment status } & Full time & 115 & 57.2 \\
\hline & Part time & 51 & 25.4 \\
\hline & More than full time & 35 & 17.4 \\
\hline & Total & 201 & 100 \\
\hline \multirow{3}{*}{ Income } & Less than 15,000 baht per month & 57 & 28.4 \\
\hline & $15,000-25,000$ baht per month & 37 & 18.4 \\
\hline & $25,001-35,000$ baht per month & 38 & 18.9 \\
\hline
\end{tabular}




\begin{tabular}{|c|c|c|c|}
\hline & $35,001-45,000$ baht per month & 36 & 17.9 \\
\hline & $45,001-55,000$ baht per month & 11 & 5.5 \\
\hline & $55,001-65,000$ baht per month & 13 & 6.5 \\
\hline & $65,001-75,000$ baht per month & 5 & 2.5 \\
\hline & $75,001-85,000$ baht per month & 1 & 0.5 \\
\hline & $85,001-95,000$ baht per month & 2 & 1.0 \\
\hline & More than 95,000 baht per month & 1 & 0.5 \\
\hline & Total & 201 & 100 \\
\hline \multirow{6}{*}{ Learning Objectives } & As a hobby. & 47 & 23.4 \\
\hline & To use for work. & 10 & 5.0 \\
\hline & To use in my classroom. & 10 & 5.0 \\
\hline & For self-development. & 57 & 28.4 \\
\hline & To learn something new. & 77 & 38.3 \\
\hline & Total & 201 & 100 \\
\hline \multirow{7}{*}{$\begin{array}{l}\text { Place where } \\
\text { connection to Internet } \\
\text { is used. }\end{array}$} & Home & 40 & 19.9 \\
\hline & Office & 17 & 8.5 \\
\hline & School or University & 28 & 13.9 \\
\hline & Library & 8 & 4.0 \\
\hline & Café/Coffee Shop & 39 & 19.4 \\
\hline & Mobile network & 69 & 34.3 \\
\hline & Total & 201 & 100 \\
\hline \multirow{6}{*}{$\begin{array}{l}\text { Duration of Drawing } \\
\text { Art Education (per } \\
\text { session) }\end{array}$} & Less than one hour & 12 & 6.0 \\
\hline & 1-2 hours & 25 & 12.4 \\
\hline & 3-4 hours & 40 & 19.9 \\
\hline & 5-6 hours & 72 & 35.8 \\
\hline & More than 6 hours. & 52 & 25.9 \\
\hline & Total & 201 & 100 \\
\hline \multirow{6}{*}{ Painting equipment } & tablet & 28 & 13.9 \\
\hline & iPad & 66 & 32.8 \\
\hline & computer & 19 & 9.5 \\
\hline & Mobile Phone/Smartphone & 70 & 34.8 \\
\hline & E-Sketchbook & 18 & 9.0 \\
\hline & Total & 201 & 100 \\
\hline
\end{tabular}

Table 3 shows the assessment results for the Art of Drawing course from the 19 experts. From the results, the experts indicated that the use of the basic applications as a tool for learning to draw was very appropriate $(\bar{x}=4.87, \mathrm{SD}=0.12)$, as well as the applications use on a computer $(\bar{x}=4.83, \mathrm{SD}=0.28)$. Additional comments from the experts also indicated that the M-learning concept by use of the Internet was a good channel and choice for beginners to learn the Art of Drawing with the application. In drawing, there are a variety of methods for the medium of art, such as pencil or oil, as well as equipment, but in the digital world there is a great savings to the physical art world's costs. Use of the basic drawing application on a smartphone suitability was 
also indicated by the experts as a very appropriate tool $(\bar{x}=4.80, \mathrm{SD}=0.28)$, as well as a PDA $(\bar{x}=4.73, \mathrm{SD}=0.39)$. The experts felt that although the smartphone was not as robust a tool as an iPad, PDA, or tablet, it was more useful in the sense of mobility and portability. Therefore users were more likely to use a smartphone. Also, the experts felt that the free download of E-Sketchbook is a good choice for learners who have problems with the reflection of light through the device. $(\bar{x}=4.60, \mathrm{SD}=$ 0.47). Although E-Sketchbook is available for download, there are some restrictions on downloading and printing. It is also quite tricky to use because it has many steps.

Table 3. Assessment Results of Art of Drawing M-learning Course Experts ( $n=19)$

\begin{tabular}{|l|c|l|l|}
\hline \multicolumn{1}{|c|}{ Evaluation Items } & $\overline{\boldsymbol{x}}$ & SD & \multicolumn{1}{c|}{ Results } \\
\hline $\begin{array}{l}\text { The consistency of the pattern with the drawing through the } \\
\text { underlying application of PDA or Smartphone and E- } \\
\text { Sketchbook }\end{array}$ & 4.79 & 0.42 & Very appropriate \\
\hline $\begin{array}{l}\text { Use of the basic drawing application as a learning tool for } \\
\text { drawing. }\end{array}$ & 4.87 & 0.12 & Very appropriate \\
\hline Use of the basic drawing application on a PDA & 4.73 & 0.39 & Very appropriate \\
\hline Use of the basic drawing application on a smartphone. & 4.80 & 0.28 & Very appropriate \\
\hline Use of the basic drawing application on a computer. & 4.83 & 0.33 & Very appropriate \\
\hline Use of the basic drawing on E-Sketchbook. & 4.60 & 0.47 & Very appropriate \\
\hline
\end{tabular}

Table 4 shows the 19 experts' assessment results concerning media appropriateness. From the results, the experts were shown to have consistent opinions on the use of digital tools and media as a tool for learning art by use of M-learning. The results showed that the experts felt that M-learning through YouTube was very appropriate $(\bar{x}=4.95, \mathrm{SD}=0.12)$ as it has many lessons appropriate for art drawing education and encourages continuous learning. Additionally, the experts also felt that $\mathrm{M}$ learning the art of drawing through a Facebook page was also very appropriate $(\bar{x}=$ $4.87, \mathrm{SD}=0.31$ ), as Facebook is another area to collect content in the art of drawing, is connected to YouTube, and can be used as a channel for communication between students and instructors. It also acts as a gallery or online ePortfolio for students who can present their work and exchange ideas, suggestions, and techniques [12]. The experts also commented that learning the art of drawing through interactive e-book is very appropriate $(\bar{x}=4.81, \mathrm{SD}=0.26)$, because Interactive E-book is a digital book, which has animation and art which encourages students to learn continuously. And finally, E-Sketchbook was also viewed by the experts as very appropriate as it allowed users who had trouble viewing digital devices another option $(\bar{x}=4.80, \mathrm{SD}=$ $0.30)$.

Table 4. Assessment Results of Media Approriateness by Course Experts ( $\mathrm{n}=19)$

\begin{tabular}{|l|c|c|l|}
\hline \multicolumn{1}{|c|}{ Evaluation Items } & $\overline{\boldsymbol{x}}$ & SD & \multicolumn{1}{c|}{ Results } \\
\hline Learning through an interactive e-book. & 4.81 & 0.26 & Very appropriate \\
\hline Learning through a YouTube channel. & 4.95 & 0.12 & Very appropriate \\
\hline Learning from a Facebook page. & 4.87 & 0.31 & Very appropriate \\
\hline Learn through E-Sketchbook. & 4.80 & 0.30 & Very appropriate \\
\hline
\end{tabular}


Table 5 shows the 19 experts' assessment results concerning informal art learning styles appropriateness. From the results, the experts believed that the informal learning style for art drawing education was very appropriate for both 21 st-century learning $(\bar{x}=5.00, \mathrm{SD}=0.00)$ and patterns of learning assessment (rubrics assessment scoring) $(\bar{x} 4.92, \mathrm{SD}=0.19)$. Therefore, the goal is to provide students with the ability to plan and manage their learning, as well as having the ability to assess their own learning. All other areas were also judged to be very appropriate by the experts. This included the learning process $(\bar{x}=4.89, \mathrm{SD}=0.25)$, which was in accordance with the Discipline-Based Art Education (DBAE) process, learning styles through experience $(\bar{x}=4.84, \mathrm{SD}=0.37)$, composition within the model consistent and appropriate for learning. Learn art free $(\bar{x}=4.84, \mathrm{SD}=0.25)$, the appropriateness of learning objectives $(\bar{x}=4.89, \mathrm{SD}=0.28)$ and the learning objective $(\bar{x}=4.84, \mathrm{SD}=0.19)$.

Table 5. Assessment Results of Art Learning Styles by Course Experts ( $\mathrm{n}=19)$

\begin{tabular}{|l|c|c|l|}
\hline \multicolumn{1}{|c|}{ Evaluation Items } & $\overline{\boldsymbol{x}}$ & \multicolumn{1}{c|}{ SD } & \multicolumn{1}{c|}{ Results } \\
\hline The right model for learning in the 21 st century. & 5.00 & 0.00 & Very appropriate \\
\hline Patterns appropriate to the learning style through experience. & 4.84 & 0.37 & Very appropriate \\
\hline $\begin{array}{l}\text { Elements within the style are consistent and appropriate for the } \\
\text { informal learning of art. }\end{array}$ & 4.84 & 0.25 & Very appropriate \\
\hline Suitability of learning process & 4.84 & 0.28 & Very appropriate \\
\hline Learning objectives. & 4.89 & 0.25 & Very appropriate \\
\hline The objective of the study. & 4.84 & 0.37 & Very appropriate \\
\hline Patterns of learning assessment. & 4.92 & 0.19 & Very appropriate \\
\hline
\end{tabular}

Table 6 shows the 201 students' assessment results concerning the informal Art of Drawing course learning styles appropriateness. From it and the M-learning students' survey responses, it was determined that there was great enthusiasm for the course and its appropriateness to learning in the $21^{\text {st }}$ Century $(\bar{x}=5.00, \mathrm{SD}=0.00)$, and the students' attitudes concerning the informal process of Art of Learning by M-learning $(\bar{x}=4.95, \mathrm{SD}=0.22)$. The students also felt that M-learning is consistent with promoting life skills $(\bar{x}=4.84, \mathrm{SD}=0.19)$.

Additional comments from the course participants indicated that digital tools such as PDAs and smartphones greatly assist in the process of learning art drawing informally. It makes the process easy to start, with the quality not differing from the art supplies used in a studio. In addition, the participants also had positive opinions on the appropriateness of the evaluation form $(\bar{x}=4.60, \mathrm{SD}=0.49)$, which included a post-action review (PAR) and Self Performance Assessment (SAE) that helped students see their progress in learning and performing their tasks.

Although some feel that beauty and happiness cannot be measured, there is no opposition to the concept of educational evaluation. While the samples were significant $(\bar{x}=4.50, \mathrm{SD}=0.32)$, the DBAE learning theory was satisfactory. 
Paper-M-learning for the Art of Drawing: Informal Learning for a Digital Age

Table 6. Assessment Results of Informal Art Learning Styles by Students $(\mathrm{n}=201)$

\begin{tabular}{|l|c|c|l|l|}
\hline \multicolumn{1}{|c|}{ Evaluation Items } & $\overline{\boldsymbol{x}}$ & SD & \multicolumn{1}{|c|}{ Results } \\
\hline The content was with art theory (DBAE). & 4.48 & 0.33 & Very appropriate \\
\hline The learning style is consistent with promoting life skills. & 4.84 & 0.19 & Very appropriate \\
\hline The self-assessment model was appropriate. & 4.57 & 0.49 & Very appropriate \\
\hline $\begin{array}{l}\text { The Informal Art of Drawing course is consistent with promoting } \\
\text { learning in the } 21^{\text {st }} \text { Century. }\end{array}$ & 5.00 & 0.00 & Very appropriate \\
\hline $\begin{array}{l}\text { Student attitude concerning the informal process of Art of Learn- } \\
\text { ing by M-learning. }\end{array}$ & 4.95 & 0.22 & Very appropriate \\
\hline
\end{tabular}

\section{Discussion}

M-learning has been found to offer exciting new frontiers in education and pedagogy [36], with smartphones being the key factor that enables learners to use mobile technology as a learning device [37]. Research also indicates that students using tablets start to include more and more mobile learning technologies into their learning strategies, which is consistent with the findings of this study.

Mobile technology opens the door for a new kind of learning called here and now learning that occurs when learners have access to information anytime and anywhere to perform authentic activities in the context of their learning [38]. The art of drawing and painting can now take place anywhere, anytime, with M-learning an initial model for conceptual frameworks or learning styles. Combined with interactive learning materials and online learning channels, students can easily access the instructor led learning system. Mobile technologies can support learning across different contexts as their portability enables them to be used by the learner in whichever context she or he is in [39].

Through the interaction process of knowledge, media, technology and equipment, the needs of the learners can be addressed through a process of blended learning [30]. E-learning also suggests a way of self-regulated activities so that active learning strategies can be implemented, which is very helpful, because the students are responsible for their own learning and they get involved in the teaching rather than just receiving simple lectures, such as tutorials or presentations [40]. As online learning often encompass both e-learning and blended learning, it generally refers to the idea of using online tools for learning.

In the Art of Drawing M-learning course, instructors have the opportunity to customize their content and mix and match software and digital tools to suit the level of skills and technological capability of their students. It also creates a unique learning experience, which is creative and unique. Additionally, online connections through social media networks such as Facebook, provide a social learning system [12-13], which allows the exchange of activities and ideas.

Enrichment of context-aware technologies has enabled students to learn in an environment that integrates learning resources from both the real world and the digital world [41]. The next generation of the digital world will include interaction within the entire environment where embedded devices will be more intelligent, with instant and 
continuous connectivity to large networks like the internet [40]. As the average US smartphone user touches their phone 2617 times a day, the reality is the smartphone has added another 'sense' to a human's toolkit of devices (eyes, ears, brain, etc.) for information collection and storage [42].

The addition of the virtual classroom allows students to access freely the vastness of the world's art and museums. It also allows the ability to exchange information with experts never before possible, which can create an endless learning cycle. An important aspect in the field of teaching lies in the shift of interest from the function of a museum being only of an exhibition-informational nature, to a second being of a constructive-expressive nature [43].

Also, from the study's survey, it was determined that $34.3 \%$ were taking the course over a mobile network, and did so 'to learn something new' $(38.3 \%)$ or 'for selfdevelopment' (28.4\%). M-learning now allows learning activities that fits into their daily lives where the learner is at the center of learning, and where the learner is highly motivated to learn at their own pace.

Using M-learning for the Art of Drawing also permits students who are 'shy' to participate in learning a skill that they might otherwise choose not to in a more formal setting such as a studio with other students. The learner can now remove barriers to learning, whether it be distance, time, language, 'shyness', being handicapped, or cost.

And finally, the DBLE theory consisted of four topics including, performing arts, artistic aesthetics, art history, and critique of art. Most students are only interested in the first two topics, where art history is only of interest to some. Therefore, most of the samples did not focus on performance evaluation and criticism, because art students have their own way of working or technique, so there are different ways of looking at beauty and different aesthetic attitudes.

\section{Conclusion}

Using M-learning for the Art of Drawing is not a new idea, as ePortfolios in Higher Education (HE) have been used in the USA, Australia and New Zealand since the 1990s. More recently, they have been increasingly used by European higher education institutions, such as previously discussed in Austria. HE with ePortfolio means sustainable, reflective, and deep learning. It means handing over the ownership of learning to the student, and with the 'elephant in the room' the smartphone, Mlearning has become the platform/digital tool of choice to do so.

There is no doubt that the smartphone and its technological successors are here to stay. Formal HE, however, is a slow moving machine which appears to be ever more falling behind other 'informal' channels of learning, which can adapt and change as the technology changes. In the art world, as with any profession, there are naysayers concerning the use of technology where for thousands of years the artist studio, and their paint, canvas, and brush ruled. However, this study showed there is great excitement building for moving this art form into a modern, $21^{\text {st }}$ Century, digital world. We hope this study conveys that excitement. 


\section{$7 \quad$ References}

[1] Matin, F., \& Parker, M. A. (2014) Use of synchronous virtual classrooms: Why, who, and how? MERLOT Journal of Online Learning and Teaching, 192-210. Retrieved from https://tinyurl.com/zvkva58

[2] Jacob, S. M., \& Issac, B. (2008). Mobile technologies and its impact- An analysis in higher education context. International Journal of Interactive Mobile Technologies, 2(1), 10-18. Retrieved from https://tinyurl.com/yc55xeyu

[3] Alnabhan, M., \& Aljaraideh, Y. (2014). Collaborative M-learning Adoption Model: A Case Study for Jordan. International Journal of Emerging Technologies in Learning, 9(8), 4 - 10. https://doi.org/10.3991/ijet.v9i8.3639

[4] Frohberg, D., Göth, C., \& Schwabe, G. (2009), Mobile Learning projects - a critical analysis of the state of the art. Journal of Computer Assisted Learning, 25(4), 307 - 331. https://doi.org/10.1111/j.1365-2729.2009.00315.x

[5] Taylor, J., Sharples, M., O'Malley, C., Vavoula, G., \& Waycott, J. (2006). Towards a task model for mobile learning: a dialectical approach. International Journal of Learning Technology, 2(2/3), 138 - 158. https://doi.org/10.1504/ijlt.2006.010616

[6] Engeström, Y., \& Glăveanu, V. (2012). On Third Generation Activity Theory: Interview With Yrjö Engeström. Europe's Journal of Psychology, 8(4). https://doi.org/10.5964/ejop.v8i4.555

[7] Sharples, M. (2015). Seamless Learning Despite Context. In Seamless Learning in the Age of Mobile Connectivity. In: Wong LH., Milrad M., Specht M. (Eds.) Seamless Learning in the Age of Mobile Connectivity. Springer, Singapore, (pp. 41 - 55). https://doi.org/10.1007/978-981-287-113-8 2

[8] Finkelstein, J. (2006). Learning in real time: Synchronous teaching and learning online. San Francisco, CA: Jossey-Bass.

[9] Cao, Q., Griffin, T. E., \& Bai, X. (2009). The importance of synchronous interaction for student satisfaction with course web sites. Journal of Information Systems Education, 20(3), 331-338.

[10] Motteram, G. (2001). The role of synchronous communication in fully distance education. Australian Journal of Educational Technology, 17(2), 131-149. Retrieved from http://www.ascilite.org.au/ajet/ajet17/motteram.html

[11] Fulantelli, G., Taibi, D., \& Arrigo, M. (2015). A framework to support educational decision making in mobile learning. Computers in Human Behavior, 47, $50-59$. https://doi.org/10.1016/j.chb.2014.05.045

[12] Dorninger, C., \& Schrack, C. (2008). Future learning strategy and ePortfolios in education. International Journal of Emerging Technologies in Learning, 3(1), 11-14. https://doi.org/10.1007/978-0-387-09729-9 35

[13] Lave, E., \& Wenger, E. (1991). Situated Learning. Legitimate peripheral participation. Cambridge, UK.

[14] Queirós, R., Oliveira, L., Leal, J. P., \& Moreira, F. (2011). Integration of ePortfolios in Learning Management Systems. Lecture Notes in Computer Science, $500-510$. https://doi.org/10.1007/978-3-642-21934-4 40

[15] Amabile, T. M. (1983). The social psychology of creativity. New York, NY: SpringerVerlag. https://doi.org/10.1007/978-1-4612-5533-8

[16] Morse, K. (2017, June 6). Developing creative thinking skills through art. Retrieved from https://tinyurl.com/y74sgwzq

[17] Greer, W. D. (1984). Discipline-Based Art Education: Approaching art as a subject of study. Studies in Art Education, 25(4), 212-218. Retrieved from http://www.jstor.org/ stable/1320414 
[18] Eisner, E. W. (1987). The role of discipline-based art education in America's schools. Art Education, 40(5). https://doi.org/10.2307/3193012

[19] Arnstine, D. (1990). Art, aesthetics, and the pitfalls of discipline - based art education. Educational Theory, 40(4). https://doi.org/10.1111/j.1741-5446.1990.00415.x

[20] Stankiewicz, M. A. (2000). Discipline and the Future of Art Education. National Art Education Association, 301-313. Retrieved from https://tinyurl.com/ybqnp8lh

[21] Barkan, M. (1966). Curriculum problems in art education. In E. L. Mattil (Ed.), A seminar in art education for research and curriculum development (USDE Cooperative Research Project No. V-002) (pp. 240-255). University Park: The Pennsylvania State University.

[22] Wolf, R. (1990). Using audio-visual programs with teaching direction in teaching still life drawings to fifth-grade students. Glassboro, New Jersey: Glassboro State College.

[23] Isaacs, M. R. (1999). A comparison of two methods for teaching art and their influences on students' creativity. (Master's Thesis). Rowan University. Retrieved from http://rdw.rowan.edu/etd/1824

[24] Bidarra, J., Figueiredo, M., \& Natálio, C. (2015). Interactive Design and Gamification of eBooks for Mobile and Contextual Learning. International Journal of Interactive Mobile Technologies, 9(3). https://doi.org/10.3991/ijim.v9i3.4421

[25] Usal, Y., \& Şirin, A. (2015). M-learning in Art-Education. International Journal of Learning and Teaching, 1(2), 129 - 133. Retrieved from https://tinyurl.com/yaz7x36n

[26] Mehdipour, Y., \& Zerehkafi, H. (2013). Mobile learning for education: Benefits and challenges. International Journal of Computational Engineering Research, 3(6), 93 - 101. Retrieved from https://tinyurl.com/y7n7sev5

[27] Sarrab, M. (2012). Mobile Learning (M-learning) and Educational Environments. International Journal of Distributed and Parallel Systems, 3(4), $31-38$. https://doi.org/10.5121/ijdps.2012.3404

[28] Vázquez-Cano, E. (2014). Mobile Distance Learning with Smartphones and Apps in Higher Education. Educational Sciences: Theory \& Practice, 14(4), 1505 - 1520. https://doi.org/10.12738/estp.2014.4.2012

[29] Shamsuddin, A. K. (2013). Digital painting: The trouble-free appearance of virtual thought and pretends. Journal of Modern Science and Technology, 2(2), 51-58. Retrieved from https://tinyurl.com/ycy6nnhy

[30] Banyen, W., Viriyavejakul, C., \& Ratanaolarn, T. (2016). A Blended Learning Model for Learning Achievement Enhancement of Thai Undergraduate Students. International Journal of Emerging Technologies in Learning, 11(4), 48-55. http://dx.doi.org/10.3991/ ijet.v11i04.5325

[31] Van Dijk, J. A. G. M. (1990). Delphi questionnaires versus individual and group interviews. Technological Forecasting and Social Change, 37(3), $293-304$. https://doi.org/10.1016/0040-1625(90)90029-u

[32] Pogany, W. (1996). The Art of Drawing. New York, NY: Madison Books.

[33] Humble, Á. M. (2009). Technique Triangulation for Validation in Directed Content Analysis. International Journal of Qualitative Methods, 8(3), 34 - 51. https://doi.org/10.1177/ 160940690900800305

[34] Best, J. W. (1981). Research in Education. (4th ed.). New Jersey: Prentice - Hall Inc.

[35] Delcker, J., Honal, A., \& Ifenthaler, D. (2018). Mobile device usage in higher education. Digital Technologies: Sustainable Innovations for Improving Teaching and Learning, 45 56. https://doi.org/10.1007/978-3-319-73417-0 3

[36] Shih, Y., \& Mills, D. (2007). Setting the new standard with mobile computing in online learning. The International Review of Research in Open and Distance Learning, 8(2). 1-16.

[37] Suki, N. M., \& Suki, N. M. (2010). The usage of mobile device for learning: A case study. IJUTFD, 1(1). pp. 1-11. Retrieved from http://eprints.ums.edu.my/id/eprint/2819 
[38] Martin, F., \& Ertzberger, J. (2013). Here and now mobile learning: An experimental study on the use of mobile technology. Computers \& Education, 68, 76 - 85. https://doi.org/10.1016/j.compedu.2013.04.021

[39] Jones, A. C., Scanlon, E., \& Clough, G. (2013). Mobile learning: Two case studies of supporting inquiry learning in informal and semiformal settings. Computers \& Education, 61, 21 - 32. https://doi.org/10.1016/j.compedu.2012.08.008

[40] Yengin, İ, Karahoca, D., Karahoca, A., \& Yücel, A. (2010). Roles of teachers in elearning: How to engage students \& how to get free e-learning and the future. Procedia Social and Behavioral Sciences, 2(2), 5775 - 5787. https://doi.org/10.1016/j.sbspro. 2010.03.942

[41] Chen, C-C., \& Huang, T-C. (2012). Learning in a u-museum: Developing a context-aware ubiquitous learning environment. Computers \& Education, 59(3), 873 - 883. https://doi.org/10.1016/j.compedu.2012.04.003

[42] Adhikari, S. (2017). Learning to live with, and control, intelligent machines. The Weekend Australian. Retrieved from https://tinyurl.com/y79yq9eh

[43] Panciroli, C., Russo, V., \& Macauda, A. (2017). When technology meets art: Museum paths between real and virtual. Proceedings, 1(9), 913 - 927. https://doi.org/10.3390/ proceedings 1090913

\section{Authors}

Chananchida Yuktirat is a doctoral student in the Architectural Education and Design Program at the Faculty of Industrial Education and Technology at the King Mongkut's Institute of Technology Ladkrabang (KMITL), Bangkok, Thailand. Presently, she is teaching an undergraduate curriculum in creative and product design division at Rajabhat Institute Suansunandha University (SSRU), where she also earned a B.S. in Industrial Design. Her M.S.I.Ed. (Technology of Industrial Product Design) is also from KMITL. Her interests include instructional industrial designing, craft product designing, creative economy, art, crafts, and Thai local wisdom. She has also served as an educator and Director of Pikanesri Art and Design Center and acted as an Adviser to the Ministry of Commerce for OTOP Brands.

Apisak Sindhuphak is an Assistant Professor of Industrial Design at the Faculty of Industrial Education and Technology at the King Mongkut's Institute of Technology Ladkrabang (KMITL), Bangkok, Thailand. His expertise is in automotive styling, indigenous local materials, mass-customization design processes, biotechnology, and higher-education curriculum design. He also organizes course curriculum for the design division and acts as an operations assistant in the Architectural Education Department. He is also acts as a reviewer for several Thai academic journals.

Krissana Kiddee is an Assistant Professor at the King Mongkut's Institute of Technology Ladkrabang (KMITL), Bangkok, Thailand. Her focus is on educational research, measurement and evaluation, project evaluation and curriculum development. She also acts as a reviewer for several Thai academic journals and acts as an operations assistant in the Postgraduate Specialist Program under the Curriculum Development and Evaluation Research office.

Article submitted 10 July 2018. Resubmitted 16 August 2018. Final acceptance 20 August 2018. Final version published as submitted by the authors. 